\title{
Examining availability of ICT tools for use in enhancing teaching and learning in Secondary Schools in Rachuonyo South Sub-County, Homa- bay County, Kenya
}

\author{
Obonyo Samson Odhiambo \\ Department of Curriculum Studies, Great LakesUniversity of Kisumu,Kenya \\ Dr. Yambo, John M. Onyango, PhD. \\ Department of Educational Administration, Planning and Economics, Kisii University, \\ Eldoret Campus, Kenya \\ Email: yambojm@gmail.com
}

\begin{abstract}
The purpose of this study was to investigate the use of Information Communication Technology (ICT) in teaching and Learning in Rachuonyo South District secondary schools. The focus was on three main subject matters: on ICT use and competence, on teacher and student and on ICT infrastructure and teaching practices. The objective of this study was to examine availability of ICT tools for use in enhancing teaching and learning. A descriptive survey design was used. Data from the field was collected through the use of questionnaire and an observation schedule. From the sample area of study, there were 320 students drawn from form four. In addition, 24 teachers, and 8 principals were purposively selected to fill questionnaires designed for them. Reliability of the instruments was addressed through piloting in 5 schools and reliability coefficients were obtained by subjecting the instruments to a Split-half Technique and Spearman "Brown Prophesy formula" .To ensure face and content validity of the research instruments, 2 experts in the department of curriculum studies, faculty of education were requested to scrutinize the research instruments so as to validate them. Data was analyzed using both qualitative and quantitative methods. Qualitative data was analyzed using likert scale and other qualitative data were analyzed in an ongoing process as themes and sub-themes emerged.The findings further indicated that ICT integration realized some challenges such as availability of sufficient number of ICT tools, lack of motivation and support and lack of technical support. The challenges are either teacher-level (Micro-level), school level (Meso-level) or system level (Macro-level). These barriers have hindered successful implementation of ICT into teaching and learning processes. The study also recommended that teachers should be given sufficient training on how to use ICT tools to enhance teaching and learning in schools. The study also recommended that students should be equipped with ICT skills such as Microsoft software applications such as word, excel and access. Finally, further research on the perception of teachers and students towards the use of ICT in enhancing teaching and learning and relevant strategies for using ICT to improve teaching and learning practices should be conducted.
\end{abstract}

Keywords: Kenya, availability, ICT, enhancing, teaching, learning, implementation

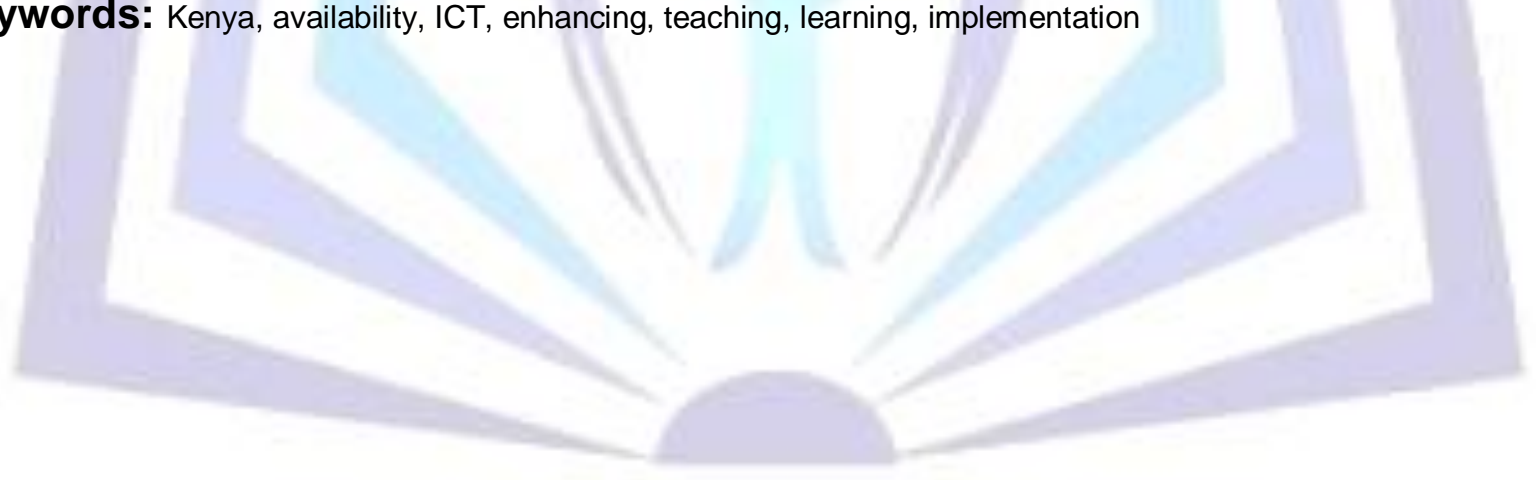

\section{Council for Innovative Research}

Peer Review Research Publishing System

Journal: Journal of Social Sciences Research

Vol .7, No.2

jssreditor.cir@gmail.com

www.jssronline.com

1325 | P a g e

April 27, 2015 


\section{Introduction}

Studies done in Britain by Pelgrum (2005) pointed out that the use of Information Communication Technology (ICT) in education and training has been a priority in most European countries during the last decade, but progress has been uneven. In most developed countries such as UK, schools have embedded the use of ICT in teaching and learning into the curriculum and demonstrate high level of effective and appropriate use to support teaching and learning Organization for Economic Cooperation and Development, (OECD,2004). ICT is defined as the seamless incorporation of technology to support and enhance students' engagement in meaningful learning and for attainment of curriculum adjectives. The rapid growth of the global economy and the information based society has pressurized education systems around the world to use ICTs to teach the knowledge and skills they need in the $21^{\text {st }}$ Century (World Bank, 2004). The growth of the ICT sector has challenged teachers to prepare for effective use of the new teaching and learning tools in their teaching profession. Research done by UNESCO (2002),Bouwer (2003) and Chisenga (2006) argued that there are significant benefits of using ICT as part of teaching and learning process as long as teachers recognize the relationship between the use of ICT and overall curriculum implementation. Similar studies done by Jegede, Odusola, \& Ilori (2007) equally pointed out that different ICTs and well spelt out curriculum innovation, do make some valuable contributions to various parts of educational

development and effective learning through expanding access, promoting efficiency, improving the quality of learning, enhancing quality teaching and improving management systems.

\section{Statement of the Problem}

The use of information and communication technology in Kenyan education is lagging behind expectation and desire. This was revealed by the fact that while most secondary schools have some computer equipment; only a fraction was equipped with basic ICT infrastructure necessary for teaching and learning. Essentially, ICT in education is used to promote information literacy that is the ability to access use, evaluate information from different sources so as to enhance teaching and learning, solve problems and generate new knowledge. Furthermore, United Nations and the World Bank affirms that ICT can increase access to education network for students, teachers and broaden availability of quality education material for emerging global economies.Despite the government efforts to equip schools with proper ICT curriculum, however, it was notedthat Rachuonyo South sub-county in Homabay County like many other sub-counties in the country was still limited to computer usage in secondary schools. Statistics from the county education office Rachuonyo South indicated that only eight Secondary schools had embraced the integration of ICT out of eighty-five Secondary schools in the subcounty. This signified that over 90 percent of the schools had not embraced ICT in their curriculum. This described the use of ICT in the sub-county as almost negligible. This meant that learning outcomes of the students in secondary in thesubcounty might be dismal due to the absence of ICT in most of the secondary schools in the district.Therefore, the researcher intended to find out the use of computers in teaching and learning process and its subsequent effects in Rachuonyosub-county schools with a view of providing solution.

\section{Availability of ICT tools for use in enhancing teaching and learning}

The term Information Communication Technology (ICT) has had a long history in its evolution process. According to Potosky and Bobko (2001) their study found out that towards the end of 1980's, the term 'computers' was replaced by IT (Information Communication Technology). This signified as shift of focus from computing technology to the computers enhancement capability to store and retrieve information. This was followed by the introduction of the term 'ICT' around 1992, when e-mail started to become available to the general public. The concept of Information Communication Technology consists of three words. Research done by Ojera and Yambo (2014) contended that communication in education is of paramount importance such that the flow of information should be well set and channeled. The term 'Information' therefore, refers to any communication or representation of knowledge such as facts, data or opinion in any medium. 'Communication' is an integral part of human existence especially in the teaching fraternity. It refers to the process of transferring information from a sender to a receiver with the use of a medium in which the Communication Information is understood by both. 'Technology' is the practical form of scientific knowledge or the science of application of knowledge.

Therefore, Information Communication Technology (ICTs) is commonly defined in education as 'a diverse set of technological tools and resources used to communicate, create, disseminate, store and manage information' (Anderson \& Dexter 2002). These technologies include computers, the internet, broadcasting technologies (Radio and Television), and (Mobile) telephony. Basically ICT is a tool. It can be hardware (such as Computers, Digital cameras), software (such excel, discussion forum) or both.

Studies done by Russell, Bebell, O'dwyer, \& O'Cannor (2003) indicated that integrating ICT in to teaching and learning is not a new concept. It may be as old as other technologies such as radios or televisions. However, with the rapid development of emerging technologies, such as web technology, ICT integration has increasingly attracted the attention of educators. Technology should be used not because it is available or it has been shown effective in some cases. It should be used to enable the process and enhance learning because inappropriate use of technology can lead to negative effects. Integration has a sense of completeness or wholeness (Grabbe\& Grabbe, 2007). by which all essentials elements of a system are seamlessly combined together to make a whole. In education, simply handing out to students a collection of websites or CD-ROM programmes; taking your students to the computer lab once a week or using an electronic worksheet is not necessarily ICT integration. In a properly prepared ICT integrated lesson, ICT and other crucial educational components such as content and pedagogy are molded into one entity. As a result, Russell et al. (2003) 
concluded that the objective of the lesson may be achieved: but if the ingredients were taken away from the ICT integrated lesson, the quality of the lesson would be somehow be diminished.

According to Yambo and Tuitoek (2014) in their study done among high school principals opined that instead, technology is integrated when it is used in a seamless manner to support and extend curriculum objectives and to engage students in a meaningful learning. This consequently yields better summative education results. It is not something one does separately; it is part of the daily activities taking place in the classroom. Based on this evidence, schools should embrace the current technology to boost the education sector in Kenya. ICT integration is more of a process rather than a product. The computer should be fitted into the curriculum not the curriculum into the computerEurydice (2005). Therefore, effective ICT integration should focus on pedagogy design by justifying how the technology is used in such a way and why. Effective ICT integration into learning process has the potential to engage learners. Additionally, ICT can support various types of interactions in the learning environment: learner - content, learner- learner, learner-teacher and learner-interface. These types of interactions make the learning process more interactive and learners more active and engaged Wong and Mill (2006). Research done by Hawkins (2004) andYambo (2012) pointed out that many educators perceive computers as just another burden, commenting on the lack of awareness among educators of the potential offered by computers in education context, and noting that education have tended in consequence to confine the possibilities of computer use towards processing and e-mail. Other researchers such as Pascopella, (2001) emphasize that some educators felt that computers served only a recreational function, with learners being allowed, for instance, to play games after computing work. However, Potosky and Bobko, (2001) demonstrated that computer use has a positive impact on teaching and learning.

\section{Methodology}

This study used descriptive survey design. The descriptive survey research design is used for its appropriateness in making reality known through collecting detailed factual information that describes existing phenomena at a given moment in time (Vyhmeister, 2001).Sampling makes it possible to draw valid inferences or generalizations on the basis of careful observation of variables with a relatively small proportion of the population. (Best and Khan, 2008) in this study, only eight schools in the district were included. All the schools in this sub county were considered, hence purposive sampling.From the sample area of study, there were 320 students drawn from form four for they have been in school longer than others. In addition, 24 teachers, and 8 principals were purposively selected to fill questionnaires designed for them. Thus, total sample of respondents was 352 .

Pilot questionnaires were divided into two equivalent halves and their correlation confident for the two halves computed using the Spearman Brown prophecy formula, describing the internal consistency of the test then it shows that the instrument is reliable, according to Saunders and Adrian (2003)minimum correlation coefficient of 0.65 and above is considered reliable. Both quantitative and qualitative data analysis were used in data analysis, hence mixed method. Quantitative data involved both descriptive and inferential statistics. Descriptive statistics such as frequencies counts, percentages, and means were used (Best \& Khan (2008). Ethically, researchers assured the respondents of the confidentiality. The researchers endeavored to cite ever source referred to so as to avoid plagiarism of any kind.

\section{Results and Discussion \\ Establishment of ICT departments}

The principals were asked to indicate if they have ICT departments in their schools. Their responses were as follows: All the 8 principals (100\%) revealed that they had established ICT department in their schools. However, from the observation schedules, it was revealed that though all the principals (100\%) had established ICT departments but the provision for adequate infrastructure appeared to be the least concerns to the secondary school principals. This findingwas supported the work of Yambo and Tuitoek (2014) when they contended that high school principals should in fore front in implementing ICT in schools.

\section{Accessing the internet}

Principals were asked to indicate whether teachers and students are able to access the internet. Their responses were sought and analyzed. The findings were summarized in table. 1.1

Table 1.1Accessing the internet by Teachers and Students

\begin{tabular}{lllllll}
\hline Category & \multicolumn{2}{l}{ Frequency Distribution } & \multicolumn{4}{l}{ Percentage Distribution } \\
\hline \multirow{3}{*}{ Teachers } & Yes & No & Total & Yes & No & Total \\
\cline { 2 - 7 } Students & 7 & 1 & 24 & 87.5 & 12.5 & 100.0 \\
& 4 & 4 & 320 & 50 & 50 & 100.0 \\
\hline
\end{tabular}

As shown in table 1.1, majority of the principals reported that teachers were able to access the internet. A few indicated that teachers were not able to access the internet with this evidence, majority of teachers in the secondary schools are 
ready to use ICT in teaching and learning on the other hand, the observation, schedule revealed that teachers relied on eternal technical support provided by an ICT champion in the district. Russell et al. (2003) supported this idea though they postulated that integrating ICT in to teaching and learning is not a new concept. There is necessity to provide internal technical support for active use and full integration, as the interest might increase positive outcomes especially the delivery of educational services to students. Half of the principals $(50 \%)$ reported that students were able to access the internet while another half $(50 \%)$ reported that students were not able to access the internet. This suggests that students experience need to be improved in order to ensure full integration of ICT in teaching and learning.

\section{Using ICT in teaching and learning}

The principals were asked to indicate if teachers are able to use ICT for teaching. Four principals (50\%) indicated that teachers were able to use ICT in teaching and learning. $37.5 \%$ of the principals revealed that some of the teachers were able to use power point presentations while $12.5 \%$ (1 principal) indicated that no teacher could use ICT in teaching and learning. Majority of the teachers (50\%) were able to use ICT in classrooms. This implies that an increasing number of teachers are embracing integration of ICT in education hence the nation's development with earlier warning cited by (Odhiambo 2005) that the low ICT capacities of teachers would have serious implications for the nation's development efforts. Together, these findings reveal that thought secondary school teachers acquired computer skills, they to a less extend made use of ICT for teaching and learning in schools.

\section{Availability of ICT personnel in the schools.}

The principals were asked to indicate the availability or unavailability of various personnel in the ICT department. Their responses are as indicated in table. 1.2

Table 4.12.Availability of ICT Personnel in the School.

\begin{tabular}{lcc}
\hline ICT Personnel & Frequency & Percentage (\%) \\
\hline ICT Coordinator & 6 & 75 \\
Computer Specialist & 3 & 37.5 \\
\hline Total & 9 & 100
\end{tabular}

Data in table 1.2 indicated that majority of principals had ICT coordinator and a few had computer specialists. Majority of the schools therefore did not have an ICT specialist. This calls for comprehensive policies enhancing schools to have ICT specialists who can provide technical support to ICT beginners to broaden access to computer to enhance quality and develop both students and teachers' knowledge and skills responsive to changing teaching and learning opportunities. It is worth mentioning that efficient ICT use has the potential that can indeed foster new learning environment with improved learning outcomesGrabbe\& Grabbe(2007).

\section{Availability of various ICT}

The principals were asked to indicate the availability or unavailability of various information communication technologies. The results were analyzed as follows in table 1.3

\section{Table 1.3 Availability of various ICTs in the Schools}

\begin{tabular}{ll}
\hline Internet Facilities & Radio \\
\hline Available and Adequate (25\%) & Available and Adequate (37.5\%) \\
Available and inadequate (62.5\%) & Available and inadequate (25\%) \\
Not available 12.5\% & Not available 37.5\% \\
\hline & \\
\hline Computer & Telephone \\
\hline Available and Adequate (62.5\%) & Available and Adequate \\
Available and inadequate (37.5\%) & Available and inadequate \\
Not available & Not available \\
\hline
\end{tabular}




\begin{tabular}{ll}
\hline $\begin{array}{l}\text { Available and Adequate } \\
\text { Available and inadequate (25\%) } \\
\text { Not available 75\% }\end{array}$ & $\begin{array}{l}\text { Available and Adequate (25\%) } \\
\text { Available and inadequate (62.5\%) } \\
\text { Not available 12.5\% }\end{array}$ \\
\hline & \\
\hline Film Projector & Cassette Recorder \\
\hline Available and Adequate (12.5\%) & Available and Adequate \\
Available and inadequate (87.5\%) & Available and inadequate (37.5\%) \\
Not available & Not available 62.5\% \\
\hline & \\
\hline Printer & T.V. Set \\
\hline Available and Adequate (37.5\%) & Available and Adequate (25\%) \\
Available and inadequate (62.5\%) & Available and inadequate (62.5\%) \\
Not available & Not available 12.5\% \\
\hline
\end{tabular}

Results in table 1.3 reveal that majority of the schools had internet facilities, which were available and inadequate while a fewschools had available and adequate internet facilities. Others did not have internet facilities.

On the other hand majority of the schools indicated to have available and inadequate film projectors. A few schools reported that they had available and adequate film projector. Majority schools reported that they had no cassette recorders, only a few schools indicated that cassette recorders were available and inadequate. Majority of the schools reported that printers were available and inadequateYambo (2012). A few schools reported to have available and adequate printers. Majority reported that T.V was available and inadequate. A few schools indicated that T.V.S were available and adequate. Other schools had no T.V.

\section{Teachers perception of the application of ICT in teaching and learning}

Respondents were asked to indicate on a five-point scale ranging strongly agree (5) to strongly disagree (1) their views on the transformative role of ICT in their teaching and learning situations.

Their feelings are shown in table. 1.4

Table 1.4 Descriptive Statistics of Teachers Perception of the Application of ICT in Teaching

\begin{tabular}{llllllll}
\hline Variables & SA $\%$ & A & U & D & SD & MEAN & ST. \\
& & $\%$ & $\%$ & $\%$ & $\%$ & & DEV \\
& & & & & & & \\
\hline & 12.5 & - & - & - & 87.5 & 1.5 & 1.32 \\
$\begin{array}{l}\text { ICT can improve teaching and learning } \\
\text { processes. }\end{array}$ & & & & & & & \\
$\begin{array}{l}\text { Computer can enhance students' critical } \\
\text { thinking skills. }\end{array}$ & 75 & 12.5 & 12.5 & - & - & 4.625 & 0.696 \\
$\begin{array}{l}\text { ICT can enhance students' participation and } \\
\text { feedback to teachers. }\end{array}$ & & 12.5 & 12.5 & 12.5 & 50 & 1.625 & 1.218 \\
$\begin{array}{l}\text { ICT cab enhance collaboration among } \\
\text { students }\end{array}$ & & 12.5 & 12.5 & 12.5 & 50 & 1.625 & 1.409 \\
$\begin{array}{l}\text { ICT can enhance teacher and student } \\
\text { interaction }\end{array}$ & 62.5 & 37.5 & - & - & - & 4.625 & 0.484 \\
Internet can offer opportunities to teachers & 62.5 & 25 & 12.5 & - & - & 4.5 & 0.707
\end{tabular}
for obtaining learning resources to improve course content 


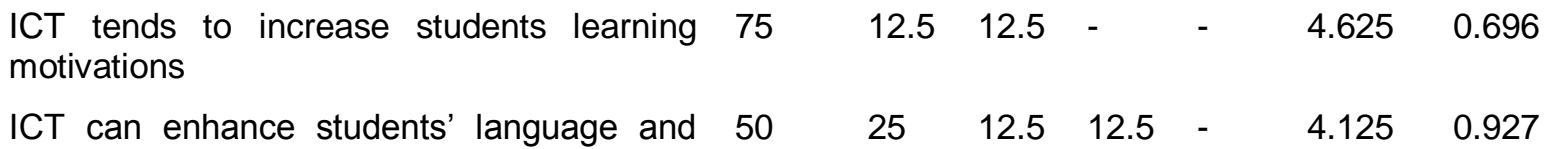
writing skills

Scale: SA = Strongly Agree: $A=$ Agree: $U$ = Undecided: $D=$ Disagree: SD = Strongly Disagree

The findings of the study revealed that $(75 \%$, mean $=4.625)$ respondents indicated that use of computers in teaching and learning can enhance students critical thinking skills. It also revealed that $(62.5 \%$, mean $=4.5)$ of the respondents showed that ICT can enhanced teacher and student interaction and that internet can offer opportunities to teachers for obtaining learning resources to improve course content for learners. This idea was supported by Eurydice (2005) when it was pointed out ICT enhances student's aptitude. This affirms that majority of the respondents had positive perception of the application of ICT in teaching and learning. However, $(87.5 \%$, mean $=1.5)$ strongly disagreed that ICT can improve teaching and learning.

\section{Lack of access to ICT equipment}

267 teachers (83.3\%) and 20 principals (82.5\%) revealed that lack of access to ICT equipment is a major challenge in the integration of ICT in teaching and learning. As a result teachers and students do not have the opportunity to use ICT at any time according to their needs.

\section{The absence and poor quality of ICT infrastructure}

The study revealed that 18 principals $(75 \%)$ indicated that the absence and poor quality of ICT infrastructure in schools is a major hindrance to implementation of ICT. The finding is in agreement with E-learning Nordic study, which found that the absence of technology is a crucial hindrance.

\section{Conclusions}

The linking of computers to education across the world is known to many people because it is believed that ICT has a crucial impact on teaching and learning. Therefore Educational Institutions are witnessing a paradigm shift brought about by the use of ICT that others have even started seeing ICT as an indispensable tool in the teaching and learning process.

\section{Recommendations}

From the findings of the study, it is recommended that;

(i) Teachers should be given sufficient training on how to use ICT in teaching and learning processes to acquire the requisite knowledge and skills in integrating the technology in classrooms.

(ii) Teachers should also be provided with adequate technological resources, technical support and administrative support to encourage them successfully use ICT in teaching and learning.

\section{REFERENCES}

1. Anderson, R.E \& Dexter, S.L (2002) School technology Leadership: Incidence

a. and Impact centre, for research on Information Technology and Organization. University of California http://respositories.colli.org Accessed August 2007

2. Best, J. \& Khan.V. (2008). Research in Education. Boston Alyn and Bacon

3. Bouwer, A. (2003). An Integrated book-based computer assisted model to

a. development cognitive reading strategies of South African learners. South African Journal of Education 4(2) 35-59.

4. Chapman B, (2003). Assessment of Business Teacher Educators' adoption of

a. computer Technology. Virginia polytechnic instituted state University.

5. Chisenga, J. (2006). Key Paper Presented at Standing conference of African

a. National and University Libraries of Eastern, Central and Southern Africa at the Crawford Hotel in Tanzania.Committee and Development in Science of Learning (Ed.) (2002). How people learn: Brain, Mind, Experience and School. Washington DC: National Academy Press.

6. Eurydice (2005). How boys and girls are finding their way with ICT.

a. Brussels: Eurydice European Unit. Accessed at:

b. http://.eurydice.org/resources/eurydice/pdf/0integral/069EN.pdf.

7. Grabbe, M. \& Grabbe, C. (2007). Integrating Technology on meaningful

a. learning. ( $5^{\text {th }}$ edition) Boston NY: Houghton Mifflin..

8. Hawkins, R.J. (2004). Ten Lessons for ICT and Education in the Developing

a. World, Washington DC. The World Bank Institute.

9. Jegede, P.O. Odusola, O.O. Ilori, M.o (2007). Relationship between ICT

a. competence and attitude among Nigerian tertiary Institution Lectures. Educational Research and Review, 2(7), 172 - 175.

10. Ministry of Education, Science and technology/ Ministry of Information and

a. Communication.www.education.go.ke/MOESTdocs/national\%21ICT\%20strategy\%20for\%20educatio\%2 0and\%20training\%20june\%202006.pdf.

11. Network for IT-Research and Competence in Education (ITU, 2004) pilot; 
a. ICT and school development, University of Oslo, accessed at;

b. http://zalo.itu.no/ITU/filearchive/ENGpilotfv.pdf

12. OECD (2004) 'Are students ready for a technology rich world? What PISA

a. studies tell us', France: OECD. Accessed at: http://www.oecd.org/dataoecd/28/4/35995145/pdf.

13. Odhiambo, G. (2005). Teacher appraisal: the experience of Kenya secondary school

14. Teachers. Journal of Education, 43(4), 402-416.

15. Ojera, D. A. \& Yambo, J. M. O. (2014).Role of Principals' Instructional Leadership Style in facilitating learning materials and co-ordination of Personnel on Students' Performance. International Journal of Humanities and Social Science Invention March $2014,3(3) 51-\quad 55$.

16. Olson, J. (1988). School words-Micro words: Pergamum Press.

17. Pascopella, A. (2001) Laptop or Textbook? District Administrators. Toronto, Pergamum Press.

18. Pelgrum, W. J. (2005). ICT Integration, Data from International Cooperative

a. Studies.Boston NY: Houghton Mifflin.

19. Potosky, D \& Bobko, P. (2001) A model for predicting computer experience for Attitudes towards computers. Journal of Business and Psychology.3(2)44-51

20. Russel, M. Bebell, D. O'dwyer, L \& O'Cannor, K. (2003). Examining teacher

a. technology use :Technophobia Among Public School Teachers.Michigan: Zondervan

21. Saunders M., Philip L. \& Adrian T. (2003); Research methods for Business students, third edition.Prentice Hall.

22. Solomon, G. (1994). Differences in patterns: studying computer enhanced

a. learning environment. In S. Vosniadou\& E. Decorte and H. Mandl (Eds) Technology based learning environments. Heidelberg: Springer - Verlag

23. UNESCO, (2002). Information and Communication Technologies in schools:

a. A handbook for teachers on how ICT can create New Open learning Environment; France

24. Vyhmeister, N. J. (2001). Your Indispensable Guide to Writing Quality

a. Research Papers. Michigan: Zondervan

25. Wong, A. \& Mill, R.T. (2006).Singapore students and teachers perception of

a. computer supported project work classroom learning environments. Journal of Research on Technology in Education. 3(3) 77-89

26. World Bank, (2004). Contributions of ICTs Economic Growth. Washington

a. DC: The World Bank Institute

27. Yambo, J.M.O. (2012) Determinants of KCSE Examination Performance in SDA Sponsored Schools: A Key to Academic Promotion to the next Level of Learning. Lambert Academic Publishing, Saarbrucken, Germany.

28. Yambo, J. M. O. \& Tuitoek J.K.F. (2014). Effects of Principals' Decision Making in the Management of Private of Private secondary schools in Kisumu District, Kenya. International Journal of Academic Research in Progressive Education and Development June 2014, ISSN: 2226-6348 3(4)52-60. 